Article

\title{
Exploring the Relationship between Abusive Management, Self-Efficacy and Organizational Performance in the Context of Human-Machine Interaction Technology and Artificial Intelligence with the Effect of Ergonomics
}

\author{
Shanyu Lin ${ }^{1, * \mathbb{D}}$, Esra Sipahi Döngül ${ }^{2} \mathbb{D}$, Serdar Vural Uygun ${ }^{3}$, Mutlu Başaran Öztürk ${ }^{4}$, Dinh Tran Ngoc Huy ${ }^{5,6} \mathbb{D}^{\mathbb{D}}$ \\ and Pham Van Tuan ${ }^{7}$ \\ check for \\ updates \\ Citation: Lin, S.; Döngül, E.S.; \\ 1 Fuzhou University of International Studies and Trade, Fuzhou 350202, China \\ 2 Department of Social Work, Faculty of Health Sciences, Aksaray University, Aksaray 68000, Turkey; \\ esrasipahidongul@aksaray.edu.tr \\ 3 Faculty of Economics and Administrative Sciences, Nevşehir HBV University, Nevşehir 50300, Turkey; \\ serdarvuraluygun@nevsehir.edu.tr \\ 4 Faculty of Economics and Administrative Sciences, Nigde Ömer Halisdemir University, Nigde 51240, Turkey; \\ mbozturk@ohu.edu.tr \\ 5 MBA, Banking University of Ho Chi Minh City, Ho Chi Minh 700000, Vietnam; dtnhuy2010@gmail.com \\ 6 International University of Japan, Niigata 949-7277, Japan \\ 7 Faculty of Marketing, National Economics University (NEU), Hanoi 11616, Vietnam; \\ phamvantuan@neu.edu.vn \\ * Correspondence: linshanyu@fzfu.edu.cn
} Uygun, S.V.; Öztürk, M.B.; Huy, D.T.N.; Tuan, P.V. Exploring the Relationship between Abusive Management, Self-Efficacy and Organizational Performance in the Context of Human-Machine Interaction Technology and Artificial Intelligence with the Effect of Ergonomics. Sustainability 2022, 14, 1949. https://doi.org/10.3390/ su14041949

Academic Editors: Anca Draghici and Nicoleta Luminita Carutasu

Received: 23 October 2021

Accepted: 28 January 2022

Published: 9 February 2022

Publisher's Note: MDPI stays neutral with regard to jurisdictional claims in published maps and institutional affiliations.

Copyright: (c) 2022 by the authors. Licensee MDPI, Basel, Switzerland. This article is an open access article distributed under the terms and conditions of the Creative Commons Attribution (CC BY) license (https:// creativecommons.org/licenses/by/ $4.0 /)$.

\begin{abstract}
Background: Our study aims to explore the impact of abusive management and selfefficacy on corporate performance in the context of artificial intelligence-based human-machine interaction technology in enterprise performance evaluation. (2) Methods: Surveys were distributed to 578 participants in selected international companies in Turkey, Taiwan, Japan, and China. To reduce uncertainty and errors, the surveys were rigorously evaluated and did not show a normal distribution, as it was determined that 85 participants did not consciously fill out the questionnaires, and the questionnaires from the remaining 493 participants were used. By using the evaluation model of employee satisfaction based on a back propagation (BP) neural network, we explored the manifestation and impact of abusive management and self-efficacy. Using the listed real estate businesses as an example, we proposed a deep learning BP neural network-based employee job satisfaction evaluation model and a human-machine technology-based employee performance evaluation system under situational perception, according to the design requirements of humanmachine interaction. (3) Results: The results show that the human-machine interface can log in according to the correct verbal instructions of the employees. In terms of age and education level variables, employees' perceptions of leaders' abusive management and self-efficacy are significantly different from their job performances, respectively $(p<0.01)$. (4) Conclusions: artificial intelligence (AI)-based human-machine interaction technology, malicious management, and self-efficacy directly affect enterprise performance and employee satisfaction.
\end{abstract}

Keywords: artificial intelligence; ergonomics; sustainable development management; human-machine interaction technology; BP neural network; abusive management; enterprise performance; humanmachine interface performance

\section{Introduction}

Ergonomic studies aim to eliminate dangers and accidents that may occur in the workplace and to transform it into an environment that will please people and make them happy. It is important to develop an environment that we can define as a humane 
working environment through ergonomics. This includes working in a healthy and safe environment, designing the work in accordance with human anthropometric measurements, body strength, and personal characteristics, designing tools, machinery, and equipment in accordance with human abilities, creating a psycho-socially positive work environment, and placing importance on people in working life. Globalization has changed the definition of financial markets and the mentality of trading in these markets. The fact that financial institutions have become available in various regions of the world due to globalization has reduced the possibility of closely monitoring operations. The rapid rise of emerging markets has made it necessary for financial institutions' remote offices to provide non-standard services to different customers. Cross-border investments have increased, and clearing, custody, and payment services have been centralized. The development of information systems and the decrease in communication costs have caused financial transactions to take place in electronic environments. New products and services, especially derivatives, are another factor that increases risk. Developments in derivative products, which were initially used for hedging against risks, have made the risk management process multifaceted and complex, while more complex services and products have increased operational risks. With new products and services, the variability in transaction volumes has increased, so understanding the structure of transaction volumes and their impact on the activities of the organization has become indispensable in order to ensure effective resource allocation against operational risks. In terms of adapting to changing circumstances today, the most effective way to move the organizational change process and progress to the next stage is to create creativity [1]. They discussed sustainability in the context of human factors and ergonomics [2] and applied the parent-sibling-child model to understand "which system should be maintained and for how long" [3]. Ergonomics was previously only used by people in various periods of their life, tools and equipment and in the design of the environment, and was taken into account within the framework of the suitability of talents to humans [4]. Today, however, when human-machine-environment relations are examined together, people in the working environment are healthy and productive. The necessary arrangements for them to make work meaningful have arrived. Thus, in the last half a century, developments in the field of ergonomics science have appeared to contribute to a happier workplace. The main purpose of any human-machine system is either more output or the same output with the same inputs. This is defined as efficiency. Since the person working in this system is only human, they have the right to work under humane conditions. With globalization, rapid changes and developments in technology, and increased technology-intensive production, it is one of the most important elements of production in business life. Relationships between humans and machines have become important, and their fast development and changes have revealed the necessity of regulating their relationships with the environment. Ergonomics, as a result of these studies, was born. In recent years, mechanization and robotics usage have increased in intensity, especially in the transition to Industry 4.0, and a human-machine relationship between the work environment and coordinating ergonomics has become more needed [5]. Although ergonomics is a multidisciplinary field, there are areas of health sciences (such as anatomy and physiology), engineering sciences or social sciences (such as psychology, sociology, and economics) within this field [6]. However, just like in other disciplines, ergonomics science has undergone some advances, changes and renewals relating to the innovations and needs brought by this age and technology.

When recent studies in the field of ergonomics are examined, the most important contributions within the scope of human-machine interactions come from studies with brain imaging techniques, especially those using neuroscience tools [7]. The main reason for this is that new developments are happening in Industry 4.0 today: labor-intensive work is decreasing over time in light of these developments, and technology-intensive jobs that require a greater mental workload are increasing.

As an example of these studies, Roketsan established the neuroergonomics laboratory infrastructure with its own resources at the beginning of 2017 in Turkey. As a result of the 
planned studies, it is planned to enable the development of next-generation user-oriented interfaces on the basis of neuroergonomics in the weapons systems produced by Roketsan, and to make significant contributions to Roketsan's goal of developing original products and advanced technologies [8].

Among the reasons necessitating this study is that first, there are many abusive managements operating in businesses and organizations, and we need to evaluate their effectiveness on productivity and performance. The second reason is that from the human perspective, we need to study factors affecting employee innovation and performance, employee satisfaction and emotion, employee knowledge sharing, employee deviance or anti-productive behavior, and employee turnover intentions.

When the comprehensive evaluation of corporate performance in the context of capital markets is examined from different perspectives, a scientific and effective evaluation system should ensure that employees consciously comply with company discipline. Business development needs cannot be met if businesses focus solely on financial goals and performance. Therefore, the comprehensive assessment system should consist of three parts: financial objectives, financial results and business discipline [9]. Data-driven performance management helps the company and team leaders to concentrate on factual data and perform employee performance assessments. Employees must be able to cooperate and make decisions. According to [10], AI is now an excellent way for businesses to calculate the outcomes of such partnerships. It allows for the processing of data to be carried out in real-time. Employees will otherwise have to scour various office floors for the details they need. It is okay if managers have enough time to make these decisions. As a result, AI ensures that all information is processed in a single location. These data, or employee knowledge, assist leaders and stakeholders in evaluating employee performance and sharing results with other team members. In addition, real-time analysis enables the manager to extract insights rapidly. This is because continuous performance monitoring necessitates real-time analysis. It was found that nobody wants data or knowledge that is no longer current [11]. Therefore, accurate data are supplemented by real-time analysis, which assists in enhancing overall employee performance. Moreover, it removes any psychological prejudice. Indeed, it is one of the most fundamental reasons artificial intelligence dominates performance management, measurement, and evaluation. There is also the possibility of prejudice creeping in when a single manager is in charge of their team's performance evaluations and might display favoritism towards a particular employee [12]. This is why developing a data-driven culture is crucial, with technologies such as artificial intelligence (AI) supplementing human opinion when receiving performance feedback.

Reference [13] outlines how artificial intelligence and machine learning assist in coaching younger generations who are entering the workforce in novel ways, saving time and money. After each coaching session, the AI coaching tools provide immediate feedback. They also aid in the identification of coaching needs, linguistic patterns, and strategic planning models. Artificial intelligence (AI) research has made considerable strides in solving the classic training transition issue by assisting learners in the interim between sessions with an artificially intelligent coach. AI has offered a secure environment to learn challenging, risky, or humiliating skills [14]. Coaches were traditionally recruited from the outside to train within an organization or employed by the company's own human resources department. They could be charged with maintaining and cultivating top performers or being asked to serve as a sounding board for a strategic business decisions.

Coaching is a valuable method for individuals to learn new skills, work toward goals, or simply improve their trust personally and professionally.

Employees usually feel uneasy in declarative learning. Scholars have pointed out that the primary task of improving employee performance is to cultivate employees' professional ability to further develop their minds based on their existing cognition. The mental state of employees is directly related to the management style of leaders and affects the self-efficacy of employees. The positive management of leaders can improve enterprise performance, while negative management, such as abusive management, will hurt em- 
ployees' psychology and make them slack at work, which eventually decreases enterprise performance. However, self-efficacy can increase employees' job satisfaction and trust in the enterprise. Thus, employees will work actively and will not consider leaving.

Nowadays, research is being carried out on human-machine interaction technology based on artificial intelligence. Human-machine interaction technology can realize the dialogue between human and computer through computer input and output. However, human-machine interaction technology is rarely used in corporate performance evaluation. Deep learning is a new research direction in the field of machine learning. Incorporating deep learning into machine learning can bring machine learning closer to artificial intelligence [15].

A forecasting and decision-making analytic hierarchy process (AHP) technique used for the purpose of performance was revised for evaluation and the model worked on an example in 2001 [16]. Since the essence of neural networks is to simulate the operation process of the human brain, which can process incomplete and inaccurate data more efficiently, it is favored by enterprises and used for employee satisfaction evaluation.

With the theory of organizational psychology, the human-machine dialogue system is designed based on the technology of human-machine interaction under situational perception. When abusive management and self-efficacy are combined with research on the deep learning BP neural network model and the support vector machine regression model, comprehensive influencing factors of enterprise performance are analyzed to provide a realistic basis for the application of $\mathrm{AI}$ in enterprise performance evaluation.

Our research objectives aim to address the below issues:

Issue 1: What is the relationship between abusive management and job performance and self-efficacy rating scales?

Issue 2: What are the implications from artificial intelligence-based human-machine interaction technology, malicious management and self-efficacy in terms of direct effects on corporate performance and employee satisfaction?

\section{Materials and Methods}

\subsection{Theoretical Basis of Influencing Enterprise Performance}

Organizational psychology is the study of human learning, feedback educational intervention, teaching psychology, and social psychology in the organizational environment. Its primary role is to apply psychological theories or research results to human education. Learning psychology is a branch of organizational psychology, which is used to study the psychological activities of people in the process of learning; that is, the change process of human psychology and behavior under the effect of acquired practice or accumulated experience.

\subsubsection{Relationship between Learning Styles and Employees' Professional Competence}

Generally speaking, due to social and work experience, employees have clear objectives to learn for benefit. Employees tend to accept discovery learning, which is more helpful than traditional receptive learning [17], thus obtaining abundant practical experience and thinking about the meaning of work. Therefore, it is easy to reflect on procedural knowledge and its meaning. Anderson's Law points out that procedural knowledge learning includes three processes: declarative learning, knowledge compilation, and knowledge generalization [18]. For employees, it is generally difficult to learn the first process. As a result, if enterprises want to improve employee performance, the first step is to train employees' language learning and cognitive strategies to help them learn declarative knowledge efficiently.

\subsubsection{Relationship between Learning Theory and Employees' Professional Competence}

Gagne's teaching theory is one of the most important and well known of the teaching theories based on cognitive principles. This theory is one of the necessary conditions for learning to occur [19]. The corresponding external driving force is provided for employees 
to construct positive minds through the assimilation effect and the internal principle of learning. The aim is to build capability plots and make employees adapt to real task situations.

\subsubsection{The Performance and Effect of Abusive Supervision}

Abusive management refers to the behavior of leaders towards subordinate employees during work. These practices are persistent and contain hostility toward employees, including verbal and nonverbal behaviors (excluding physical behaviors) [20].

Some researchers believe that the purpose of abusive management by leaders is to control employees, so as to achieve their own goals by intimidating employees. Abusive management behavior will first significantly enhance the psychological pain of employees, causing them to be in a negative working state [21]. Then, employee loyalty and employee withdrawal will be weakened [22]. Finally, the abusive behavior of leaders will seriously affect the harmonious working environment between employees, hurt employees' psychology, and ultimately cannot make corresponding returns to the enterprise.

\subsubsection{The Measurement and Effect of Self-Efficacy}

Self-efficacy can predict employees' emotional feedback and job performance [23]. The measurement factors of self-efficacy include environmental factors, personality traits and leadership characteristics. The power distance within the environmental factors will significantly reduce the self-efficacy of employees, while the completion of work tasks will improve the self-efficacy of employees [24]. Transformational leadership can improve employee performance on the basis of influencing self-efficacy. Inclusive leadership can forgive employees' failure, treat each employee fairly, and enhance their self-efficacy [25].

First, self-efficacy can improve the job satisfaction of employees, improve the integrity level of employees to the enterprise, reduce the degree of job burnout, and eliminate the idea of leaving the company [26]. It can positively predict the proportion of dedication, engagement, and activity in work engagement [27]. Then, in the face of stress, the strength of self-efficacy will have a direct impact on the way employees choose to cope with stress [28]. Finally, self-efficacy can positively predict employees' job performance, that is, self-efficacy is an effective index to predict employee performance [29]. For young employees, self-efficacy is directly proportional to job performance. Self-efficacy can also directly predict the performance of research and development personnel in different dimensions [30]. According to the above theory, this study analyzes the measurement and influence of self-efficacy, which is helpful to analyze the impact of employee self-efficacy on their performance under abusive management behavior.

Next, we discuss some theories relating to hypotheses of abusive management and employee performance.

In terms of theoretical research on abusive supervision, researchers generally agree with the expression of the concept of abusive supervision by [31], that is, abusive supervision is a kind of destructive leadership behavior existing in various organizations, which refers to a subordinate's perception of linguistic or non-verbal hostile behavior that is consistently displayed by a supervisor, but does not include physical contact. Research on the various aspects of abusive supervision has been gradually developed and enriched, from the definition of abusive supervision to the measurement, causes, consequences, and mechanisms of abusive supervision, and then to its response mechanism and certain degree of positive effect.

The authors of [32] used the theory of resource protection to explore the impact of the destructive behavior of leaders, such as abusive supervision on employee knowledge sharing, and the role of learning goal orientation and self-improvement motivation in regulating the above relationship. The results suggest that resource-depleted and abused employees may reduce their level of knowledge sharing. In addition, the negative effects of abusive supervision may vary based on personal factors. Therefore, in order to achieve 
organizational effectiveness through knowledge sharing, the key role of leader behavior and employee characteristics or motivations cannot be ignored.

We summarize related studies below, in Table 1.

Table 1. Summary of previous studies.

\begin{tabular}{cll}
\hline Authors & Year & \multicolumn{1}{c}{ Contents, Results } \\
\hline Cemaloğlu [33] & 2005 & $\begin{array}{l}\text { Effective management knowledge, leadership and } \\
\text { communication skills are required. It is important } \\
\text { that managers with these qualifications are } \\
\text { selected, trained and employed. }\end{array}$ \\
\hline Huy, D.T.N. [34] & 2015 & $\begin{array}{l}\text { We need standards for management and corporate } \\
\text { governance to improve performance. }\end{array}$ \\
\hline Tepper, B.J et al. [35] & 2007 & $\begin{array}{l}\text { Experiencing abusive supervision may trigger } \\
\text { strong negative emotions and responses from } \\
\text { subordinate employees. }\end{array}$ \\
\hline Kim et al. [32] & 2016 & $\begin{array}{l}\text { Abused employees may reduce their level of } \\
\text { knowledge sharing. }\end{array}$ \\
\hline Li et al. [29] & 2017 & $\begin{array}{l}\text { Self-efficacy can positively predict employees' job } \\
\text { performance, that is, self-efficacy is an effective } \\
\text { index to predict employee performance. }\end{array}$ \\
\hline Schouteten et al. [25] & 2017 & $\begin{array}{l}\text { Transformational leadership can improve } \\
\text { employee performance on the basis of influencing } \\
\text { self-efficacy. }\end{array}$ \\
\hline Dygun, S.V. and Sipahi & 2021 & $\begin{array}{l}\text { We can refer to Chinese corporate governance } \\
\text { standards that refer to management and employee } \\
\text { standards. }\end{array}$ \\
\hline B.T.T., Huy, D.T.N. [36] & $2021)$ [37] & $\begin{array}{l}\text { In the context of innovative leadership, a } \\
\text { knowledge reputation assessment model has been } \\
\text { established for commodity trading issues using a } \\
\text { design community-sourced utilities platform and } \\
\text { scoring standards in the index system. }\end{array}$ \\
\hline & &
\end{tabular}

\subsection{Evaluation Model of Employee Satisfaction Based on BP Neural Network}

Training data constitute the dataset where real training takes place, and in the validation split, it is important to improve model performance by fine-tuning the model after each period. The test set informs us about the final accuracy of the model after completing the training phase. The training set should not be too small; otherwise, the model will not have enough data. Hold-out has guided us in the method of dividing the dataset into "training" and "test" sets. We recommend using $80 \%$ of the data for training and $20 \%$ of the remaining data for the test.

(1) Modeling

Step 1: The input nodes are designed. Six evaluation indexes are used as input nodes: whether the enterprise needs to evaluate the performance, the rationality of the evaluation system dimension, the rationality of the data filling time, whether the input operation is simple and feasible, expected employee satisfaction and system maintenance investment.

Step 2: Hidden layer nodes are designed.

The hidden layer node is designed according to the following equation.

$$
\begin{aligned}
& h_{1}=\sqrt{h+l}+a \\
& h_{1}=\log _{a} h
\end{aligned}
$$

where $l$ represents the output value of the neuron, $h$ represents the input value of the neuron; and $a$ is a constant with a value ranging from 1 to 10 . 
Step 3: The output node is designed. The expert evaluation scores of the six dimensions of the input layer are set as the expected output, and the output results are compared with the expected output, so the output layer needs a neuron. Therefore, the establishment of the BP neural network employee satisfaction evaluation model configuration is: 6 input neurons, 3 hidden layer neurons, and 1 output neuron.

Step 4: The neural network function is established. The function newff $(\operatorname{minmax}(\mathrm{P}),[31]$, \{'tanisg', 'purelin'\}, 'traingd') is used to build neural networks. The input layer training function tansig belongs to the hyperbolic tangent S-type transfer functions; the output layer training function purelin belongs to the linear transfer functions.

\subsection{Interface of Employee Performance Evaluation System Based on Human-Machine Interaction Technology under the Situational Perception}

The human-machine interaction technology and data repository are applied to the employee performance evaluation system. Human-machine interaction technology provides innovative consulting methods through AI and allows information resources to bemastered and used efficiently. It operates at a high level of current distributed information processing technology and solves the thorny problems of the traditional decision-supporting system. The system structure is shown in Figure 1.

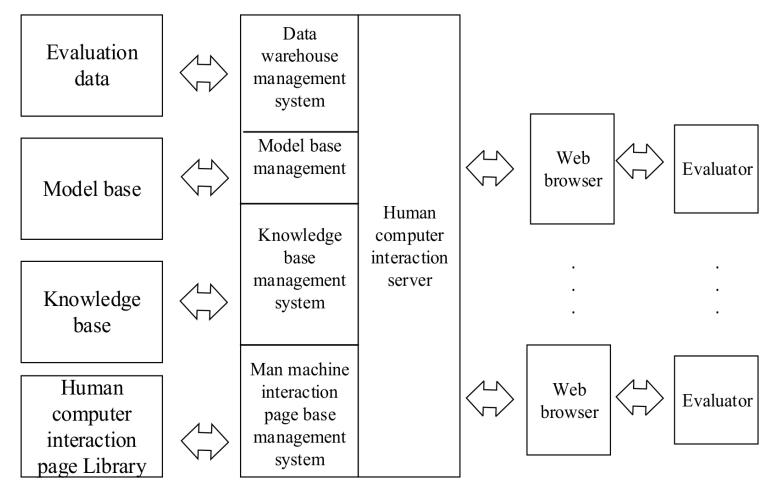

Figure 1. Framework of an evaluation system based on human-machine interaction.

The system framework contains the page library, browser, and server of the humanmachine interaction interface, replacing the traditional database with the data repository. The auxiliary system of the user interface is composed of a browser and human-machine interaction page to form a unified user interface. It has simple operation steps and is convenient to supplement system functions. If a user is added, it gives the corresponding access without installing the software again. Workers can enjoy the human-machine dialogue function in the same browser interface.

\subsection{Construction of Comprehensive Performance Evaluation Model for Real Estate Enterprises}

\subsubsection{The Principle of Support Vector Machine Regression}

A sample set $\left(a_{1}, b_{1}\right),\left(a_{2}, b_{2}\right) \ldots,\left(a_{i}, b_{i}\right)$ is determined. $a_{i} \in X^{m}, m$ represents the dimension vector (independent variable), and $b_{i} \in X$ is the dependent variable and belongs to the predicted object value. The factor value of prediction object is set as $a_{i+1}, a_{i+2}, \ldots, a_{i+m}$. It is necessary to establish a functional relationship to obtain the value of the prediction object. Therefore, the basis of constructing the support vector machine regression model is the dependent variable of the known sample data, that is, the output variable of the model, which represents the comprehensive evaluation of each object. The output variables are calculated by technique for order preference by similarity to an ideal solution (TOPSIS). If there are $y$ evaluation indexes, $\mathrm{K}$ evaluation objects, and $d_{i p}$ represents the $y$-th index value of the $k$-th evaluation object, the evaluation index matrix $U$ is expressed as follows. 


$$
U=\left[\begin{array}{cccc}
U_{11} & U_{12} & \cdots & U_{1 \mathrm{y}} \\
U_{21} & U_{22} & \cdots & U_{2 \mathrm{y}} \\
\vdots & \vdots & \vdots & \vdots \\
U_{k 1} & U_{k 2} & \cdots & U_{k 3}
\end{array}\right]
$$

\subsubsection{Data Processing}

The selected indexes are positive indexes, negative indexes and moderate indexes, and the dimension will have an impact on them, so it is necessary to model these data after assimilation. $d_{i p}$ represents the original data, and the processed data are $c_{i p}$. If $d_{i p}$ is a positive indicator, the calculation method of $c_{i p}$ is as follows:

$$
c_{i p}=\frac{d_{i p}-d_{p}^{\min }}{d_{p}^{\max }-d_{p}^{\min }}
$$

If $d_{i p}$ is a negative index, the calculation method of $c_{i p}$ is as follows:

$$
c_{i p}=\frac{d_{p}^{\max }-d_{i p}}{d_{p}^{\max }-d_{p}^{\min }}
$$

If $d_{i p}$ is a moderate index, the calculation method of $c_{i p}$ is as follows:

$$
c_{i p}=\left\{\begin{array}{cc}
1-\frac{\mathrm{w}_{p}-d_{i p}}{\max \left(\mathrm{w}_{p}-d_{p}^{\min }, d_{p}^{\max }-\mathrm{w}_{p}\right)} & d_{i p}<\mathrm{w}_{p} \\
1 & d_{i p}=\mathrm{w}_{p} \\
1-\frac{d_{i p}-\mathrm{w}_{p}}{\max \left(\mathrm{w}_{p}-d_{p}^{\min }, d_{p}^{\max }-\mathrm{w}_{p}\right)} & d_{i p}<\mathrm{w}_{p}
\end{array}\right.
$$

After data assimilation, a positive index matrix can be formed, and the value range of $c_{i p}$ is 0 to 1 . The financial data of real estate enterprises are assimilated. The factors of the object to be tested are: $a_{1}$ (earnings per share), $a_{2}$ (net asset value per share), $a_{3}$ (return on equity), $a_{4}$ (net profit margin), $a_{5}$ (current ratio), $a_{6}$ (quick ratio), $a_{7}$ (days in inventory), $\mathrm{a}_{8}$ (days sales outstanding), a (equity to asset ratio), and $\mathrm{a}_{10}$ (equity ratio). Among them, $\mathrm{a}_{1}-\mathrm{a}_{4}$ are positive indexes, $\mathrm{a}_{7}$ and $\mathrm{a}_{8}$ are negative indexes, $\mathrm{a}_{5}, \mathrm{a}_{6}, \mathrm{a}_{9}$ and $\mathrm{a}_{10}$ are moderate indexes and the moderate values are set as 2, 1, 0.6 and 1.2, respectively.

\subsubsection{Weight Value of Each Index}

The entropy weight method is used to calculate the index weight. The algorithm can use different values of each attribute weight to select each attribute, so there is no need to reduce the dimension. The calculation steps are as follows:

In the first step, the output entropy of the $i$-th index is calculated.

$$
T_{p}=-(\ln x)^{-1} \sum_{i=1}^{x} d_{i p} \ln d_{i p}
$$

where $d_{i p}=d_{i p} / \sum_{i=1}^{x} d_{i p} ; p=1,2 \cdots, m$.

The second step is to calculate the variation degree of index $p$.

$$
E_{p}=1-T_{p} ; p=1,2, \cdots, m
$$


The third step is to calculate the weight value of index $p$.

$$
w_{\mathrm{p}}=E_{p} / \sum_{p=1}^{m} E_{p} ; p=1,2, \cdots, m
$$

\subsubsection{Establishment of Support Vector Machine Regression Model}

The comprehensive evaluation value calculated by the TOPSIS method is used as the output variable of the support vector machine regression model, and the attribute value of assimilation is used as the input variable (independent variable) of the model, and then the radial basis function is selected as the kernel function of the research model. The cross validation and grid search of 82 training samples are carried out. Finally, the optimal parameter of the model is determined as $(c, g)=(0.18925,1.1469)$. Therefore, the support vector machine regression model for the comprehensive performance evaluation of real estate enterprises is obtained as follows.

$$
f(\mathrm{x})=\sum_{p=1}^{m}\left(\lambda_{p}-\lambda_{p}{ }^{\prime}\right) \exp \left(-g\left|x-x_{p}\right|^{2}\right)+s
$$

where $\lambda_{p}-\lambda_{p}{ }^{\prime}$ represents model.sv_coef (matrix of $8 \times 1$ in decision function), and $s$ stands for model.rho, which is a constant $(-0.3052)$.

\subsection{Hypothesis Test of Abusive Management and Employee Performance}

In the enterprise structure, if employees receive abusive behavior from leaders, it will have a negative impact. According to the principle of reciprocity theory [38], if a highquality relationship between leaders and employees is to form, it depends more on whether the leaders give positive and beneficial help to the subordinates [39]. If the subordinates feel the abusive behavior of the leader, they will reduce their work effort, refuse to pay, and finally reduce their work performance. This negative behavior has no benefit for the enterprise. The final result is that both task performance and relationship performance will be harmed $[40,41]$. Based on the above research topics, the following hypotheses are proposed, as shown in Table 2.

Table 2. Hypotheses of abusive management and employee performance.

\begin{tabular}{cl}
\hline Number & \multicolumn{1}{c}{ Hypothesis } \\
\hline 1 & Abusive management is negatively correlated with targeted performance \\
\hline 2 & Abusive management is negatively correlated with employee relationship \\
\hline 3 & Abusive management is negatively correlated with job performance \\
\hline
\end{tabular}

\subsection{Hypothesis Test of Self-Efficacy and Job Performance}

From the analysis of the relationship between self-efficacy and job performance, selfefficacy can directly predict employees' job performance. There is a positive correlation between employee self-efficacy and job performance [42]. People with high self-efficacy can not only effectively complete their own work, but also complete the more difficult tasks assigned by leaders. Moreover, they have strong professional ability and show excellent personal performance. This reveals that employees' self-efficacy can directly and positively affect their work performance. Therefore, the following assumptions are proposed, as shown in Table 3. 
Table 3. Hypothesis of self-efficacy and employee performance.

\begin{tabular}{cl}
\hline Number & \multicolumn{1}{c}{ Hypothesis } \\
\hline 1 & Self-efficacy is positively correlated with targeted performance \\
\hline 2 & Self-efficacy is positively correlated with employee relationship \\
\hline 3 & Self-efficacy is positively correlated with job performance \\
\hline
\end{tabular}

\section{Results}

\subsection{Demographic Information}

Table 4 exhibits the demographic data of respondents. Of the participants, 200 were female and 293 were male. This suggests that male candidates are preferred in companies. The majority of survey respondents, 224 people, were between the ages of 36 and 43 . This indicates that companies prefer to work with the middle-aged group. A total of 274 people (55.57\%) had 11-15 years of work experience, suggesting that companies prefer to work with senior people. The number of participants having graduated from PhD programs is 52 , which constitutes $10.63 \%$. In this context, employees can be directed to receive academic training.

Table 4. Demographic information.

\begin{tabular}{|c|c|c|}
\hline Gender & f & $\%$ \\
\hline Female & 200 & 40.5 \\
\hline Male & 293 & 59.5 \\
\hline Total & 493 & 100 \\
\hline Age & f & $\%$ \\
\hline $20-27$ & 62 & 12.57 \\
\hline 28-35 & 57 & 11.5 \\
\hline $36-43$ & 224 & 45.43 \\
\hline $44-50$ & 78 & 15.8 \\
\hline Above 50 & 72 & 14.7 \\
\hline Total & 493 & 100 \\
\hline Experience & f & $\%$ \\
\hline Below 3 years & 14 & 2.83 \\
\hline $3-7$ years & 47 & 9.57 \\
\hline 7-11 years & 56 & 11.35 \\
\hline $11-15$ years & 274 & 55.57 \\
\hline Above 15 years & 102 & 20.68 \\
\hline Total & 493 & 100 \\
\hline Qualification & f & $\%$ \\
\hline Bachelor & 273 & 55.3 \\
\hline Master & 168 & 34.07 \\
\hline $\mathrm{PhD}$ & 52 & 10.63 \\
\hline Total & 493 & 100 \\
\hline
\end{tabular}

\subsection{Standard Compliance Criteria}

Validating factor analysis is used for the verification of theoretical information [43]. In order for the Confirming Factor Analysis (CFA) model to be acceptable, the "compliance 
good criteria" are looked at. The proposed acceptance range of the criteria is presented in Table 5 based on [44].

Table 5. Standard compliance criteria.

\begin{tabular}{ll}
\hline Harmony Goodness Indexes & Criteria \\
\hline$\chi^{2} / \mathrm{sd}$ & $<5$ \\
\hline RMSEA & $0.00 \leq \mathrm{RMSEA} \leq 0.10$ \\
\hline RMR & $0.00 \leq \mathrm{RMR} \leq 0.10$ \\
\hline GFI & $0.80 \leq \mathrm{GFI} \leq 0.95$ \\
\hline CFI & $0.90 \leq \mathrm{CFI} \leq 0.97$ \\
\hline NFI & $0.80 \leq \mathrm{NFI} \leq 0.95$ \\
\hline NNFI & $0.95 \leq \mathrm{NNFI} \leq 0.97$ \\
\hline AGFI & $0.80 \leq \mathrm{AGFI} \leq 0.90$ \\
\hline
\end{tabular}

RMSEA—Root mean square error of approximation; RMR—Root Mean Square Residuals; GFI—goodness of fit coefficient; CFI—comparative fit coefficient; NFI—normalized fit index; NNFI—Non-normed Fit Index; AGFIadjusted goodness of fit index

When the values in Table 5 are examined, approximately 1 in the average square error of errors (RMSEA) ranges from 0 to 1 . If the resulting values are equal to or less than 0.05 , the perfect harmony indicates that values up to 0.10 are acceptable.

The goodness of fit coefficient (GFI) ranges from 0 to 1 . Values of 0.90 and above are considered a good fit, and values above 0.85 are acceptable values. The adjusted goodness of fit index (AGFI) is the adjusted GFI value taking into account the sample width. It is valued between 0 and 1 and is considered a good fit above 0.90 .

The comparative fit coefficient (CFI) is a criterion that takes into account sample size and degree of freedom in the model in the evaluation of model compliance. Having a CFI above 0.90 is considered sufficient, and above 0.95 is considered the perfect fit. The normalized fit index (NFI) ranges from 0 to 1 . Values approaching 1 indicate excellent sleep [44].

\subsection{Evaluation Results of Employee Satisfaction}

Before the BP neural network model is used to evaluate employee satisfaction, simulation training and tests are conducted to obtain the final employee satisfaction evaluation results, as shown in Figure $2 \mathrm{a}-\mathrm{c}$ below.

Figure 2a shows that when the neural network model is iterated 70 times, the whole network reaches its best. Figure $2 \mathrm{~b}$ shows that the solid line almost coincides with the dotted line, indicating that the performance of the established BP neural network is in the best state, while Figure 2c shows the output results of six dimensional variables of the BP neural network model reaching the optimal level compared with the target output value given by experts. The actual output value and target output value are very close, which shows that all the indexes of the model achieve the expected goal, that is, to achieve the expected employee satisfaction. 


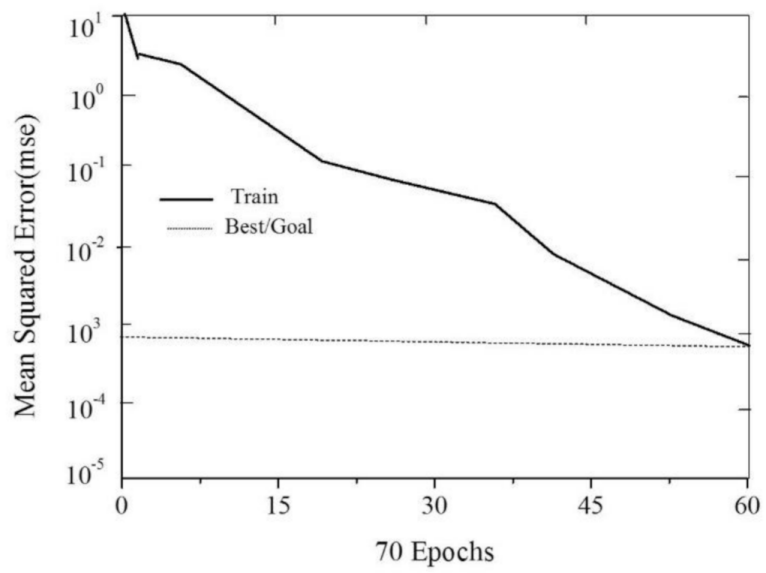

a

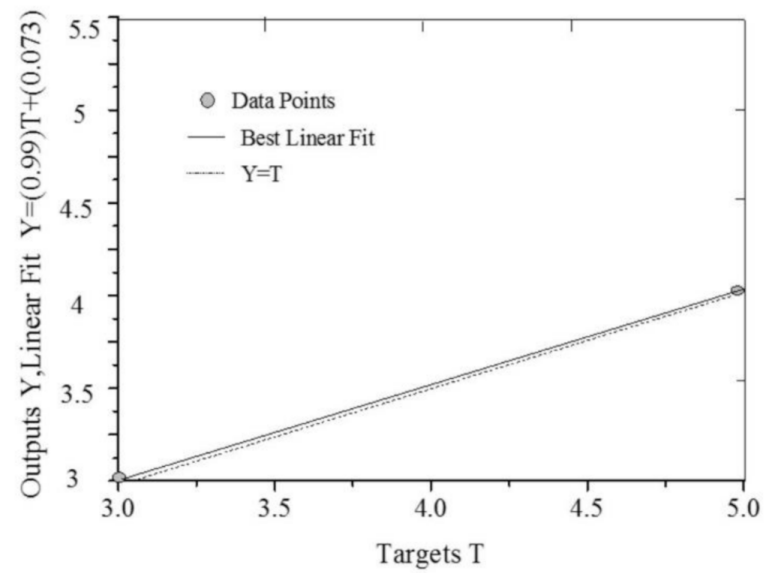

b

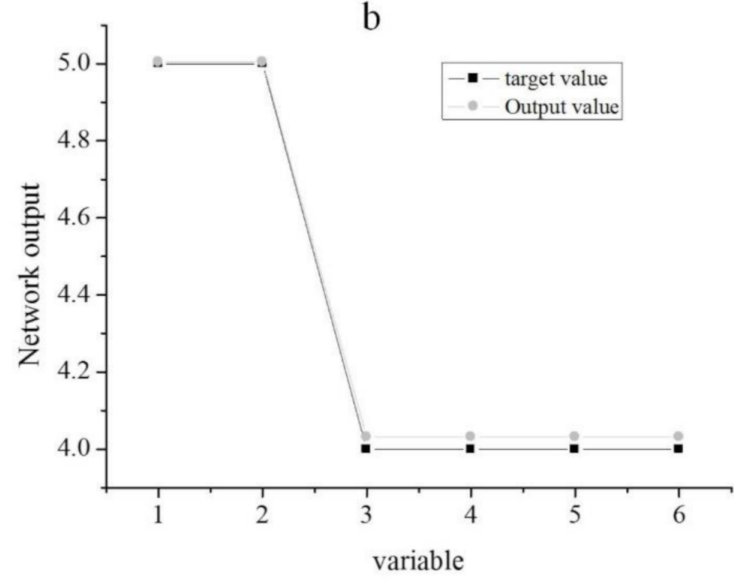

$\mathrm{c}$

Figure 2. (a) Model training results; (b) evaluation results; (c) comparison of actual output and expected output.

\subsection{Empirical Analysis of Abusive Management}

Abusive management is studied. A measurement scale of multiple dimensions and fields is developed. In the analysis of the abusive management of employees, its reliability and validity are very high. According to Tepper's maturity scale, 15 aspects are included. Employees should take self-evaluation according to the real situation of the enterprise. The contents of the scale are shown in Table 6. 
Table 6. Abusive management scale.

\begin{tabular}{cl}
\hline Number & \multicolumn{1}{c}{ Abusive Management } \\
\hline 1 & The superior ridicules the subordinate in the company. \\
\hline 3 & The superior despises the subordinate in the company. \\
\hline 4 & The superior ignores the subordinate in the company. \\
\hline 5 & The superior belittles the subordinate in the company. \\
\hline 6 & The superior offends the privacy of the subordinate in the company. \\
\hline 7 & The superior finds fault with the work of the subordinate in the company. \\
\hline 9 & The superior abuses the subordinate in the company. \\
\hline 10 & The superior does not keep the premise in the company. \\
\hline 11 & The superior becomes angry inexplicably in the company. \\
\hline 13 & The superior denigrates the subordinate in the company. \\
\hline 14 & The superior misbehaves in the company. \\
\hline 15 & The superior hinders the contacts between the subordinate in the company. \\
\hline
\end{tabular}

According to the CFA model [45], an empirical analysis of the abusive management scale was carried out. The results are shown in Figure 3.

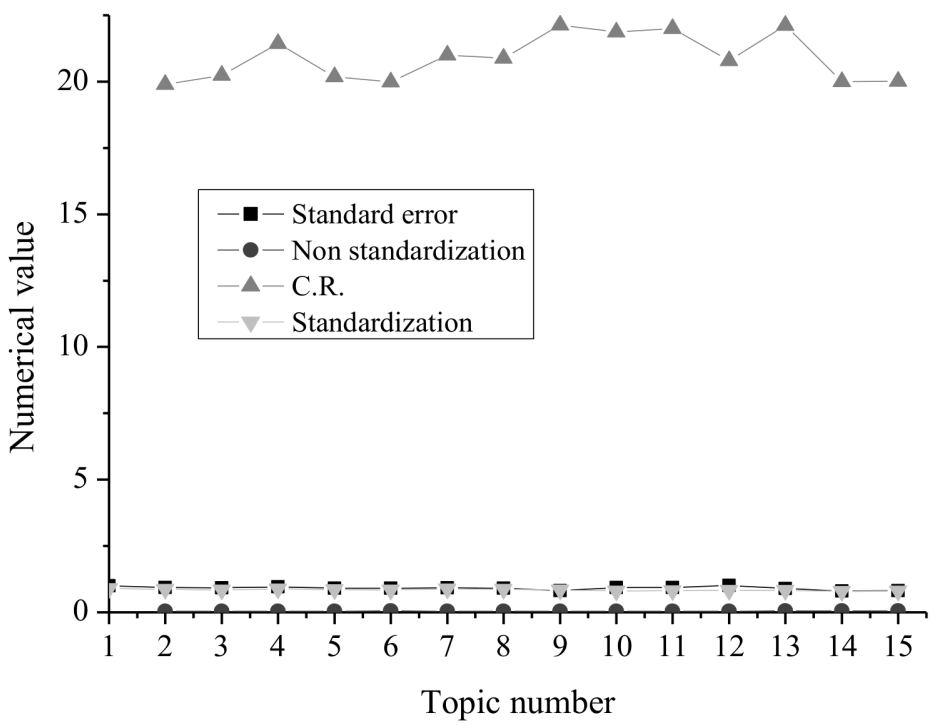

Figure 3. Results of abusive management scale $(C R=0.969 ; \mathrm{AVE}=0.679)$.

It shows $\mathrm{n}=493, \chi^{2} / \mathrm{df}=2.269, \mathrm{GFI}=0.928, \mathrm{AGFI}=0.899, \mathrm{CFI}=0.976, \mathrm{RMSEA}=0.061$, and NNFI $=0.971$. The fitness of each calculation is appropriate, and each is within the range of standard index values. Due to AVE $>0.5$, the goodness of fit and convergent validity of the model are both excellent.

\subsection{Empirical Analysis of Self-Efficacy}

The General Self-Efficacy Scale (GSES) is used for revisions, and includes ten aspects. Employees should carry out self-evaluation according to the actual situation of the enterprise. The scale contents are shown in Table 7. 
Table 7. Self-efficacy scale.

\begin{tabular}{cl}
\hline Number & \multicolumn{1}{c}{ Self-Efficacy } \\
\hline 1 & I can do my best to solve the problem. \\
\hline 2 & I will achieve my goal without the support of others. \\
\hline 3 & I think I can realize my goals. \\
\hline 4 & I think I can deal with emergencies. \\
\hline 5 & My IQ can help me to deal with accidents. \\
\hline 7 & If I work hard, I can handle the difficult task. \\
\hline 8 & I can keep calm faced with any difficulty. \\
\hline 9 & I can think of many ways to solve the problem. \\
\hline 10 & I can deal with the trouble in different ways. \\
\hline
\end{tabular}

According to the CFA model, the empirical analysis of the self-efficacy scale is carried out. The results are shown in Figure 4.

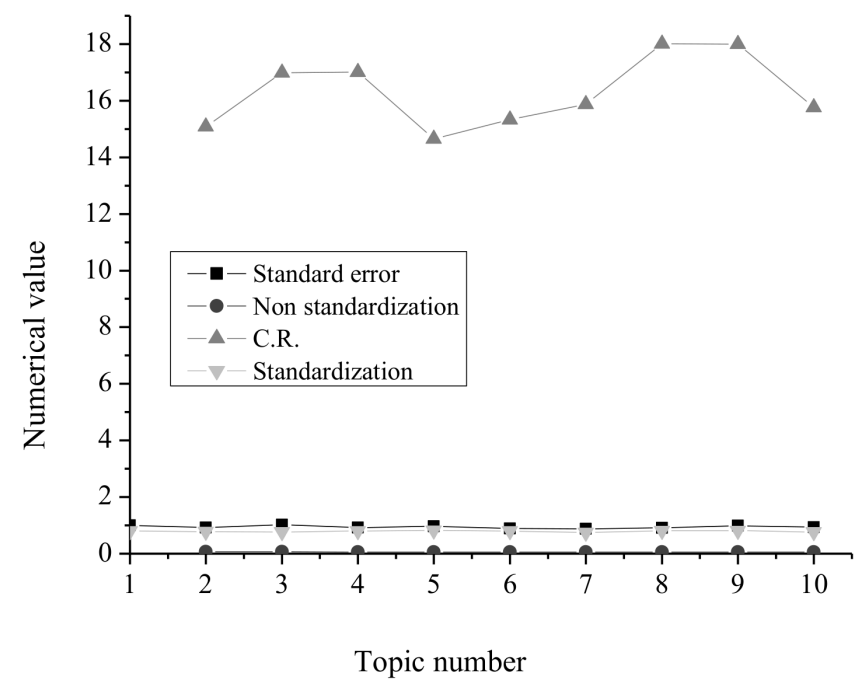

Figure 4. Self-efficacy management scales $(C R=0.599 ; \mathrm{AVE}=0.928)$.

$\mathrm{CR}$ refers to the critical ratio, $\mathrm{n}=493, \chi^{2} / \mathrm{df}=2.399, \mathrm{GFI}=0.945, \mathrm{AGFI}=0.912, \mathrm{CFI}=0.966$, RMSEA $=0.061$, and NNFI $=0.972$. The fitness of each calculation is appropriate, and each is within the range of standard index values. Due to AVE $>0.5$, the goodness of fit and convergent validity of the model are both excellent.

\subsection{Impact of Abusive Management and Self-Efficacy on Corporate Performance}

The internal coefficient of consistency (Cronbach's alpha) and validity were calculated for abusive management scale reliability. It was decided that the factor analysis was interpretable by looking at the results of the $\mathrm{KMO}$ and Bartlett's test. As a result of the reliability test applied to the scale, the internal consistency/reliability coefficient was alpha $\alpha=0.841$. It is understood that the resulting Cronbach alpha reliability coefficient is statistically sufficient and the scale is consistent and reliable.

Kaiser-Meyer-Olkin (KMO) is considered a measure of sample eligibility and is requested to be greater than 0.6. Therefore, it can be said that the data group at hand is good for factor analysis. The degree of globality (Bartlett's test of sphericity) was also found to be statistically significant, indicating that meaningful factors or variables could be extracted from the research data (Table 8). 
Table 8. Abusive management scale. Factor loads, arithmetic mean and standard deviation values related to the scale.

\begin{tabular}{|c|c|c|c|c|}
\hline Number & Abusive Management & $\begin{array}{l}\text { Factor } \\
\text { Loading }\end{array}$ & & sd \\
\hline 1 & $\begin{array}{l}\text { The superior ridicules the } \\
\text { subordinate in the company. }\end{array}$ & 0.809 & 3.82 & 0.92 \\
\hline 2 & $\begin{array}{l}\text { The superior despises the } \\
\text { subordinate in the company. }\end{array}$ & 0.805 & 3.55 & 0.90 \\
\hline 3 & $\begin{array}{l}\text { The superior ignores the } \\
\text { subordinate in the company. }\end{array}$ & 0.834 & 4.05 & 1.05 \\
\hline 4 & $\begin{array}{l}\text { The superior belittles the } \\
\text { subordinate in the company. }\end{array}$ & 0.859 & 4.09 & 1.23 \\
\hline 5 & $\begin{array}{l}\text { The superior offends the } \\
\text { privacy of the subordinate in } \\
\text { the company. }\end{array}$ & 0.843 & 4.08 & 1.21 \\
\hline 6 & $\begin{array}{l}\text { The superior finds fault with } \\
\text { the work of the subordinate in } \\
\text { the company. }\end{array}$ & 0.839 & 4.07 & 1.19 \\
\hline 7 & $\begin{array}{l}\text { The superior hinders the } \\
\text { subordinate in the company. }\end{array}$ & 0.837 & 4.06 & 1.12 \\
\hline 8 & $\begin{array}{l}\text { The superior abuses the } \\
\text { subordinate in the company. }\end{array}$ & 0.828 & 4.04 & 1.03 \\
\hline 9 & $\begin{array}{l}\text { The superior does not keep the } \\
\text { premise in the company. }\end{array}$ & 0.823 & 4.03 & 0.99 \\
\hline 10 & $\begin{array}{l}\text { The superior becomes angry } \\
\text { inexplicably in the company. }\end{array}$ & 0.813 & 4.02 & 0.97 \\
\hline 11 & $\begin{array}{l}\text { The superior denigrates the } \\
\text { subordinate in the company. }\end{array}$ & 0.811 & 4.01 & 0.95 \\
\hline 12 & $\begin{array}{l}\text { The superior misbehaves in the } \\
\text { company. }\end{array}$ & 0.808 & 3.80 & 0.88 \\
\hline 13 & $\begin{array}{l}\text { The superior hinders the } \\
\text { contacts between the } \\
\text { subordinate in the company. }\end{array}$ & 0.802 & 3.57 & 0.85 \\
\hline 14 & $\begin{array}{l}\text { The superior scorns the ability } \\
\text { of the subordinate in the } \\
\text { company. }\end{array}$ & 0.780 & 3.55 & 0.83 \\
\hline 15 & $\begin{array}{l}\text { The superior cheats the } \\
\text { subordinate in the company. }\end{array}$ & 0.629 & 2.90 & 0.81 \\
\hline \multicolumn{4}{|c|}{ - Eigenvalue } & 3.80 \\
\hline \multicolumn{4}{|c|}{ - Total Variance Disclosure Rate } & 54,279 \\
\hline \multicolumn{4}{|c|}{ - $\mathrm{KMO}$ (Kaiser-Meyer-Olkin Measure of Sampling Adequacy) } & 0.821 \\
\hline \multicolumn{4}{|c|}{ - Bartlett's Test of Sphericity } & $332,232, p=0.000$ \\
\hline \multicolumn{4}{|c|}{ - Cronbach's Alpha (Reliability Coefficient) } & 0.841 \\
\hline
\end{tabular}

When the arithmetic averages of the propositions are examined, we find $\mathrm{n}=493$, $\chi^{2} / \mathrm{df}=2.269, \mathrm{GFI}=0.928, \mathrm{AGFI}=0.899, \mathrm{CFI}=0.976, \mathrm{RMSEA}=0.061$, and NNFI $=0.971$. The fitness of each calculation is appropriate, and each is within the range of standard index values. Due to AVE $>0.5$, the goodness of fit and convergent validity of the model are both excellent.

As a result of the reliability test applied to the scale, the internal consistency/reliability coefficient was alpha $\alpha=0.839$. This result shows that the scale is reliable [46]. The 
statistical significance of the figure obtained as a result of Bartlett's test of sphericity indicates the applicability of factor analysis to variables. The fact that the KMO value (0.598) is $>0.50$ indicates that the sample is sufficient [47] (Table 9).

Table 9. Self-efficacy scale. Factor loads, arithmetic mean and standard deviation values related to the scale.

\begin{tabular}{|c|c|c|c|c|}
\hline Number & Self-Efficacy Scale & $\begin{array}{l}\text { Factor } \\
\text { Loading }\end{array}$ & $\bar{x}$ & sd \\
\hline 1 & $\begin{array}{l}\text { I can do my best to solve the } \\
\text { problem. }\end{array}$ & 0.863 & 4.03 & 1.04 \\
\hline 2 & $\begin{array}{l}\text { I will achieve my goal without } \\
\text { the support of others. }\end{array}$ & 0.861 & 4.02 & 1.02 \\
\hline 3 & I think I can realize my goals. & 0.865 & 4.04 & 1.07 \\
\hline 4 & $\begin{array}{l}\text { I think I can deal with } \\
\text { emergencies. }\end{array}$ & 0.866 & 4.05 & 1.09 \\
\hline 5 & $\begin{array}{l}\text { My IQ can help me to deal with } \\
\text { accidents. }\end{array}$ & 0.843 & 3.82 & 0.83 \\
\hline 6 & $\begin{array}{l}\text { If I work hard, I can handle the } \\
\text { difficult task. }\end{array}$ & 0.853 & 3.88 & 0.93 \\
\hline 7 & $\begin{array}{l}\text { I can keep calm faced with any } \\
\text { difficulty. }\end{array}$ & 0.855 & 4.0 & 0.96 \\
\hline 8 & $\begin{array}{l}\text { I can think of many ways to } \\
\text { solve the problem. }\end{array}$ & 0.850 & 3.86 & 0.91 \\
\hline 9 & $\begin{array}{l}\text { I can deal with the trouble in } \\
\text { different ways. }\end{array}$ & 0.857 & 3.01 & 0.74 \\
\hline 10 & $\begin{array}{l}\text { I can handle everything } \\
\text { confidently. }\end{array}$ & 0.859 & 4.02 & 1.00 \\
\hline \multicolumn{4}{|c|}{$\begin{array}{l}\text { - } \text { Eigenvalue } \\
\text { - Total Variance Disclosure Rate } \\
\text { - KMO (Kaiser-Meyer-Olkin Measure of Sampling Adequacy) } \\
\text { - Bartlett's Test of Sphericity } \\
\text { - Cronbach's Alpha (Reliability Coefficient) }\end{array}$} & $\begin{array}{l}1.851 \\
61,685 \\
0.598 \\
69,017, p=0.000 \\
0.839\end{array}$ \\
\hline
\end{tabular}

The $t$-test was used to analyze the differences in the employees' age and education level. The results are shown in Figure 5a,b below.

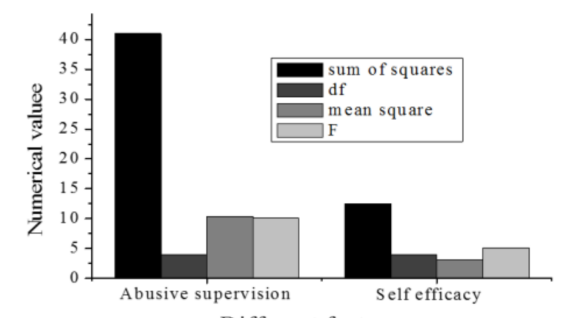

Different factors

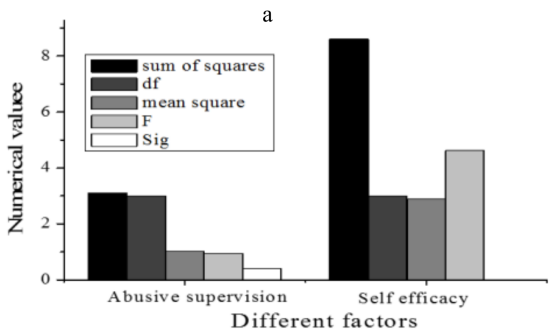

b

Figure 5. The impact of abusive management and self-efficacy on corporate performance: (a) age as a variable; (b) education as a variable. 
When the arithmetic averages of the propositions are examined, Figure 5a shows that in terms of age, employees' perception of the leader's abusive management and job performance have extremely significant differences $(p<0.01)$. Figure $5 \mathrm{~b}$ shows that in terms of education level, there is a dramatically significant difference between self-efficacy and job performance $(p<0.01)$.

\subsection{Enterprise Performance Evaluation}

The dependent variable data of test samples were input into the model to obtain the output prediction value of real estate enterprise performance evaluation under the support vector machine regression model. Figure 6 shows the results.

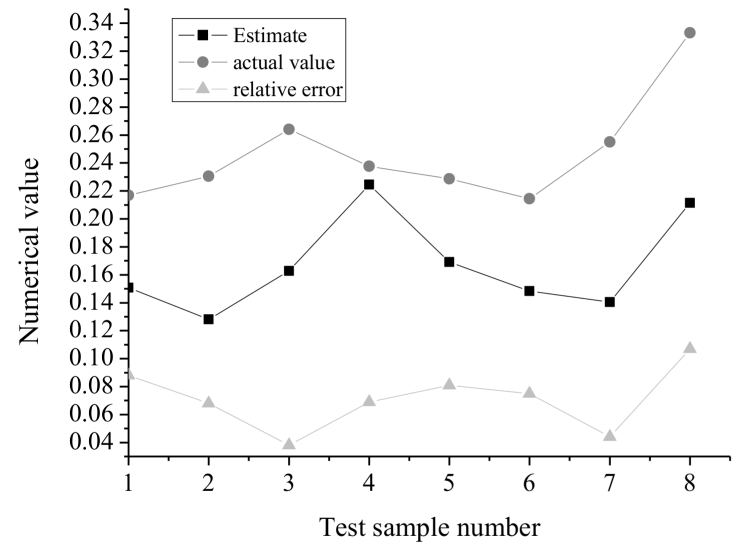

Figure 6. Output results of support vector machine regression model.

Figure 6 shows that the output results of the model are close to the prediction results. Especially in the fourth sample, the output results are basically consistent with the prediction results. Moreover, the overall trend fluctuation of the error curve of the two methods is relatively small, which indicates that the support vector machine regression model can correctly predict the real performance of real estate enterprises.

\section{Discussion}

Artificial intelligence's ability to enhance applicant and employee involvement by automating routine, low-value responsibilities, thus freeing up time to concentrate on more planned, innovative work that teams need and want to do, has been a burning topic in the research world for years. Technology may lead to improved recruitment, performance evaluations, training, and career management approaches [48]. The results show that abusive management has a significantly negative correlation with job performance. This is consistent with the research results of [49]. In the enterprise, leaders provide support and resources for employees, and employees actively accept them. At the same time, employees can improve their performance in their work projects. Moreover, they may actively take actions outside their own business to promote the development of the enterprise, which returns to the enterprise. If employees suffer from the abusive management of leaders, they will experience negative emotions psychologically, exhibit less understanding and take less action for work. Finally, they will work in a slow and orderly manner, leading to a decrease in work performance. At the same time, negative emotions can also cause employees' unwillingness to maintain good relations with colleagues and leaders, which hurts relationship performance.

There is a positive correlation between employees' self-efficacy and job performance $(p<0.01)$, which is consistent with the research results of [50]. Self-efficacy represents the self-confidence of employees to complete their tasks. When employees have a strong sense of self-efficacy, they will have faith that they can achieve their goals through their efforts. In an enterprise, employees with a strong sense of self-efficacy know how to overcome difficulties in completing tasks. At the same time, they are full of self-confidence, 
and their work performance will also be improved accordingly. By achieving set goals, employees can also be more confident in further carrying out the work plan, and will be able to help their colleagues. The majority of respondents (55.57\%) had $11-15$ years of work experience. In this context, staff with less seniority can be directed to provide in-service training. This improves the work performance of employees, strengthens collaboration between employees and ensures the formation of a company that is sharing and also highly motivated. If the control is acted upon together, as in [31], employees will be less affected by malicious control. Academic referrals can be made through in-service trainings, because there were more PhD graduates in the results of the survey. With a neural network, the thoughts of employees can be clarified. This could enable the development of nextgeneration user-oriented interfaces based on neuroergonomics in the weapons systems produced by Roketsan, and make significant contributions to the goal of developing unique products [8].

The human-machine dialogue system is designed based on human-machine interaction technology under situational perception. A B/S network calculation model is used to integrate the human-machine interaction with the data repository. Based on the traditional support system and human-machine interaction server, the system can operate the Internet, which is consistent with the research results of [51]. The BP neural network model proposed has the best comprehensive performance, which is in line with the expected value of employee satisfaction, also consistent with the research results of [52]. In order to analyze the relationship between abusive management, self-efficacy and enterprise performance, a support vector machine regression model based on machine learning is proposed. The model with optimized parameters can accurately predict the performance of real estate enterprises, and the error curve is relatively gentle, which is consistent with the research results of [53]. The human-computer interaction technology under artificial intelligence can better realize the efficient coordination and application of heterogeneous databases. At the same time, deep learning technology can also be integrated with employee satisfaction evaluation.

Regarding abusive management and job performance, the authors of [31] mentioned that for subordinates who remained with their jobs, abusive supervision was associated with lower job and life satisfaction, lower normative and affective commitment, higher continuance commitment, conflict between work and family, and psychological distress. Organizational justice mediated most of these effects, and job mobility moderated some of the deleterious effects of abusive supervision.

Next, the authors of [54] stated that safe production behavior refers to employees' compliance with safe production operating procedures, participation in various safety activities, and the improvement of safe production. In other words, as a separate area of work performance, safety behavior includes two components, safety compliance and safety participation.

Then, the authors of [55] stated that leadership behavior has an impact on the behavior of employees. Previous studies mainly focused on the impact of positive leadership behaviors on employees' behaviors. However, there is an absence of research on the impact of negative leadership behaviors (abusive supervision) on safety behaviors (including safety participation and safety compliance). This study found that abusive supervision is negatively related to employee safety behaviors (safety compliance and safety participation); that safety motivation plays a mediating role in the relationship between abusive supervision and employees' safety behavior; and that conscientiousness moderates the role of safety motivation between the relationship of abusive supervision and employees' safety behaviour. With a higher level of conscientiousness, the indirect relationship between abusive supervision and employee safety behaviors is weaker. The training of artificial intelligence requires a new human-machine symbiosis that offers innovative job sharing between machines and humans. Considering the significant improvement in AI capabilities in recent years, our article goes beyond this vision and develops the concept of human-machine cooperation in the context of advantages. It also contributes to the 
understanding of how AI can support and increase human decision making. According to [56]: "In line with the vision of human-machine symbiosis, it makes more sense to see $\mathrm{AI}$ as a tool for increasing (expanding human capabilities) from automation (rather than replacing them)".

\section{Conclusions}

The main purpose of modernization and the use of technology in production systems is to increase production. This targeted increase in production, while enhancing employee enjoyment, is made possible with applications and the science of ergonomics. The rapid pace of technology development has not only changed the nature of work but also the quality of the workforce, resulting in a more talented and a competent workforce, with improved efficiency, and physical, mental, and social protection. By taking the necessary precautions, it is necessary to provide the most suitable working environment conditions for the employee. With an ergonomic working environment, the quality of production and the desired efficiency will be achieved with the guidance of learning psychology theory in educational psychology. Abusive management has a significant negative correlation with job performance. The abusive behavior of leaders will weaken trust among employees and weaken the loyalty and responsibility of employees to the enterprise. Self-efficacy shows the personal characteristics of employees, which can directly predict employees' work engagement. The research results also suggest that self-efficacy can affect enterprise performance. Only when enthusiasm is fully mobilized can employees actively participate in the work. The human-machine dialogue system is based on human-machine interaction technology under emotional perception. The system's interface can facilitate the coordination and application of heterogeneous databases among colleges and universities on the Internet. To summarize, from the perspective of educational psychology, the performance of the BP neural network is in its best state, and all indexes reach the expected employee satisfaction. The output of the support vector machine regression model is close to the prediction result, and the overall trend of the error curve of the two is small, which shows that the support vector machine regression model can correctly predict the real performance of real estate enterprises and provide an effective method for enterprises to evaluate employees' self-efficacy and job satisfaction. However, the results remain to be improved. Due to cultural diversity, the analysis of abusive management is very complicated without the support of one-to-one data and is not comparable. Meanwhile, whether the answers of the respondents in the survey are scientific or not cannot be decided, which affects the preciseness of the research results. This is also a problem to be solved in further study.

Last but not least, the arrangement and design of human-machine interactions at workplace and the human-machine dialog system design also need to ensure productivity and effective occupational risk management, and this will involve the meaning of ergonomics. Next, in terms of age and education level variables, employees' perceptions of leaders' abusive management and self-efficacy are connected to their job performance, and in fact, synergies exist among age, education, abusive management, job performance, and sustainability. Finally, malicious management and self-efficacy directly affect corporate performance and employee satisfaction and hence, the sustainability of both business and jobs. Ergonomics, with the aim of ensuring productivity and the quality of employees' health, safety, and comfort, strives to improve its performance and improves the quality of life. The effectiveness of ergonomics, in terms of the strength and nature of working life understood by all interested parties, is of great importance. The next century, as the integration of ergonomics into working life continues, will be the era of ergonomics.

Hence, compared with previous studies, which focus more on the relationship between an abusive supervisor and job performance, this study has shown more relating to the human-machine interaction aspect, i.e., the human-machine dialog system is based on human-machine interaction technology under emotional perception, which affects job performance. This is the novelty of the research. 
Our study was limited to 493 participants working for international companies from Turkey, Taiwan, Japan and China in 2019. Authors can more deeply analyze both the positive and negative sides of abusive management and its relationship with productivity and business or team performance. Alternatively, authors can separate groups of industries and use the same model to compare results between industries. Since the findings of this study are limited to the sample it represents, there can be no generalization of these results for all countries. However, given that the number of studies on this subject is inadequate, this research is important in terms of shedding light on the work to be carried out next.

Author Contributions: Conceptualization, S.L. and E.S.D.; methodology, E.S.D., S.V.U. and M.B.Ö.; literature review, E.S.D. and S.L.; validation, P.V.T. and D.T.N.H.; investigation, M.B.Ö.; resources, E.S.D.; data accusation, S.L.; writing—original draft preparation, E.S.D.; writing—review and editing, S.L. All authors have read and agreed to the published version of the manuscript.

Funding: This research received no external funding.

Institutional Review Board Statement: Ethical review and approval were not sought for this study, because according to national regulations (Ethics Committee Permission in TURKEY, ULAKBIM TR DIRECTORY Committee, https:/ / confluence.ulakbim.gov.tr/pages/viewpage.action?pageId= 97583694\&preview=/97583694/100434212/EtikKurulOnayBelgesiSemas\%C4\%B1.pdf, accessed on 8 February 2022) retrospective ethics committee approval is not required for articles that used research data before 2020 (research data for this article have been obtained in January 2019).

Informed Consent Statement: Informed consent was obtained from all subjects involved in the study.

Data Availability Statement: The data presented in this study are available on request from the corresponding author.

Acknowledgments: The authors are grateful to the anonymous referees of the journal for their extremely useful suggestions to improve the quality of the article.

Conflicts of Interest: The authors declare no conflict of interest.

\section{References}

1. Sipahi, E. Creativity and the importance of business management. Int. J. Sci. Eng. Res. 2017, 8, 426-439. Available online: https://www.academia.edu/36473312/CREATIVITY_AND_THE_IMPORTANCE_OF_BUSINESS_MANAGEMENT (accessed on 19 September 2021).

2. Wilson, J.R. Fundamentals of systems ergonomics/human factors. Appl. Ergon. 2014, 45, 5. [CrossRef] [PubMed]

3. Thatcher, A.; Yeow, P.H. Human factors for a sustainable future. Appl. Ergon. 2016, 57, 1-7. [CrossRef] [PubMed]

4. Baslo, M. Ofis Ergonomisi Sırt ve Boyun Ağrıların Önlemek İçin Ofis Ortamını Düzenlemek; Sempozyum Dizisi No: 30; Mayıs, İ.Ü., Ed.; Cerrahpaşa Tip Fakültesi Sürekli Tıp Eğitimi Etkinlikleri: Istanbul, Turkey, 2002; pp. 155-165.

5. Kaya, S. Ergonomi ve Çalışanların Verimliliği Üzerine Etkileri Ar-Ge Bülten, A ğustos. 2008. Available online: http://www.izto. org.tr/portals/0/iztogenel/dokumanlar/ergonomi_ve_calisanlarin_verimliligi_s_kaya_26.04.2012\%2020-39-20.pdf (accessed on 21 October 2021).

6. Karamik, S.; Seker, U. İşletmelerde İş Güvenliğinin Verimlilik Üzerine Etkilerinin Değerlendirilmesi, Gazi Üniversitesi Fen Bilimleri Dergisi Part C: Tasarım ve Teknoloji. Gazi Univ. J. Sci. Part C: Des. Technol. 2015, 3, 575-584.

7. Kosti, M.V.; Georgiadis, K.; Adamos, D.A.; Laskaris, N.; Spinellis, D.; Angelis, L. Towards an Affordable Brain Computer Interface for the Assessment of Programmers' Mental Workload. Int. J. Hum. Comput. Stud. 2018, 115, 52-66. [CrossRef]

8. Roketsan Dergisi. Available online: http://www.roketsan.com.tr/wpcontent/uploads/2018/03/RoketsanDergisi-12-Say\%C4 \%B1-Ocak-2018.pdf (accessed on 12 September 2021).

9. Muhammad, N.; Scrimgeour, F.; Reddy, K.; Abidin, S. The relationship between environmental performance and financial performance in periods of growth and contraction: Evidence from Australian publicly listed companies. J. Clean. Prod. 2015, 102, 324-332. [CrossRef]

10. Jarrahi, M.H. Artificial intelligence and the future of work: Human-AI symbiosis in organizational decision making. Bus. Horiz. 2018, 61, 577-586. [CrossRef]

11. Floridi, L.; Cowls, J.; Beltrametti, M.; Chatila, R.; Chazerand, P.; Dignum, V.; Luetge, C.; Madelin, R.; Pagallo, U.; Rossi, F.; et al. AI4People-An Ethical Framework for a Good AI Society: Opportunities, Risks, Principles, and Recommendations. Minds Mach. 2018, 28, 689-707. [CrossRef]

12. Guan, W.; Ni, Z.; Hu, Y.; Liang, W.; Ou, C.; He, J. Clinical characteristics of coronavirus disease 2019 in China. N. Engl. J. Med. 2020, 382, 1708-1720. [CrossRef] 
13. Yogesh, K.; Dwivedi, E.I.; Hughes, D.L.; Carlson, J.; Filieri, F.; Jacobson, J.; Jain, V.; Karjaluoto, H.; Kefi, H.; Krishen, A.S.; et al. Setting the future of digital and social media marketing research: Perspectives and research propositions. Int. J. Inf. Manag. 2021, 59, 102168. [CrossRef]

14. Puaschunder, J.M. The Legal and International Situation of AI, Robotics and Big Data with Attention to Healthcare. Report on behalf of the Eu-ropean Parliament European Liberal Forum. 2019. Available online: https://ssrn.com/abstract=3472885 (accessed on 4 September 2021).

15. Lemley, S.J.; Bazrafkan, P. Corcoran. Deep learning for consumer devices and services: Pushing the limits for machine learning, artificial intelligence, and computer vision. IEEE Consum. Electron. Mag. 2017, 6, 48-56. [CrossRef]

16. Yaralığlu, K. Performans değerlendirmede analitik hiyerarşi prosesi. Dokuz Eylül Üniversitesi İktisadi İdari Bilimler Fakültesi Derg. 2001, 16, 129-142. Available online: https:/ /dergipark.org.tr/tr/pub/deuiibfd/issue/22766/B243002 (accessed on 17 September 2021).

17. Menon, V. Memory and cognitive control circuits in mathematical cognition and learning. Prog. Brain Res. 2015, 227, 159-186. [CrossRef]

18. Trigeorgis, G.; Bousmalis, K.; Zafeiriou, S. A deep matrix factorization method for learning attribute representations. IEEE Trans. Pattern Anal. Mach. Intell. 2017, 39, 417-429. Available online: https://arxiv.org/pdf/1509.03248.pdf (accessed on 8 August 2021). [CrossRef]

19. Schunk, D.H. Gagne'nin Öğretim Kuramı Temelinde Yapılandırılmış Piyano Derslerinde İşbirlikli Öğrenme Yönteminin İşlevselliği. OPUS Int. J. Soc. Res. 2020, 16, 4097-4137. [CrossRef]

20. Zellars, K.L.; Tepper, B.J.; Duffy, M.K. Abusive supervision and subordinates' organizational citizenship behavior. J. Appl. Psychol. 2002, 87, 1068-1076. [CrossRef]

21. Belias, D.; Koustelios, A.; Sdrolias, L. Job Satisfaction, Role Conflict and Autonomy of employees in the Greek Banking Organization. Procedia Soc. Behav. Sci. 2015, 175, 324-333. [CrossRef]

22. Park, C.H.; Kim, W.; Song, J.H. The Impact of Ethical Leadership on Employees' In-Role Performance: The Mediating Effect of Employees' Psychological Ownership. Hum. Resour. Dev. Q. 2015, 26, 385-408. [CrossRef]

23. Hutting, N.; Detaille, S.I.; Heerkens, Y.F. Experiences of participants in a self-management program for employees with complaints of the arm, neck or shoulder (CANS): A Mixed Methods Study. J. Occup. Rehabil. 2017, 27, 35-48. [CrossRef]

24. Angelika, L.; Norbert, T.; Jiménez, P. Expectations of bank employees on the influence of key performance indicators and the relationship with job satisfaction and work engagement. Soc. Sci. 2018, 7, 99. [CrossRef]

25. Schouteten, J.J.; De Steur, H.; Sas, B.; De Bourdeaudhuij, I.; Gellynck, X. The effect of the research setting on the emotional and sensory profiling under blind, expected, and informed conditions: A study on premium and private label yogurt products. J. Dairy Sci. 2017, 100, 169-186. [CrossRef]

26. Eibl, B.; Lang, F.R.; Niessen, C. Employee voice at work: The role of employees' gender, self-efficacy beliefs, and leadership. Eur. J. Work. Organ. Psychol. 2020, 1, 1-16. [CrossRef]

27. Day, A.; Crown, S.N.; Ivany, M. Organisational change and employee burnout: The moderating effects of support and job control. Saf. Sci. 2017, 4, 4-12. [CrossRef]

28. Ivey, G.W.; Blanc, J.; Sébastien, R.; Mantler, J. An Assessment of the overlap between morale and work engagement in a nonoperational military sample. Occup. Health Psychol. 2015, 20, 4-12. [CrossRef] [PubMed]

29. Li, M.; Wang, Z.; Gao, J.; You, X. Proactive Personality and Job Satisfaction: The Mediating Effects of Self-Efficacy and Work Engagement in Teachers. Curr. Psychol. 2017, 36, 48-55. [CrossRef]

30. Alessandri, G.; Borgogni, L.; Schaufeli, W.B. Erratum to: From Positive Orientation to Job Performance: The Role of Work Engagement and Self-efficacy Beliefs. J. Happiness Stud. 2015, 16, 811. [CrossRef]

31. Tepper, B.J. Consequences of Abusive Supervision. Acad. Manag. J. 2000, 43, 178-190. [CrossRef]

32. Kim, S.L.; Lee, S.; Yun, S. Abusive Supervision, Knowledge Sharing, and Individual Factors: A Conservation-of-Resources Perspective. J. Manag. Psychol. 2016, 31, 1106-1120. [CrossRef]

33. Cemaloğlu, N. Türkiye'de okul yöneticisi yetiştirme ve istihdamı: Var olan durum, gelecekteki olası gelişmeler ve sorunlar Gazi Eğitim Fakültesi Dergisi 2005, 25, 249-274. Available online: http://www.gefad.gazi.edu.tr/tr/pub/issue/6756/90858 (accessed on 23 August 2021).

34. Huy, D.T.N. The Critical Analysis of Limited South Asian Corporate Governance Standards After Financial Crisis. Int. J. Qual. Res. 2005, 9, 741-764.

35. Tepper, B.J.; Moss, S.E.; Lockhart, D.E.; Carr, J.C. Abusive Supervision, Upward Maintenance Communication, and Subordinates' Psychological Distress. Acad. Manag. J. 2007, 50, 1169-1180. Available online: http://aquila.usm.edu/fac_pubs/1899 (accessed on 19 September 2021).

36. Dat, P.M.; Mau, N.D.; Loan, B.T.T.; Huy, D.T.N. Comparative China Corporate Governance Standards After Financial Crisis, Corporate Scandals and Manipulation. J. Secur. Sustain. Issues 2020, 64, 53-70.

37. Uygun, S.V.; Döngül, E.S. Commodity-Sourced Public Service Platform-Based Commodity Information. Int. J. Soc. Humanit. Adm. Sci. 2021, 7, 1709-1720.

38. Graham, J.D.; Martin, K.A.G.; Bray, S.R. Exertion of Self-Control Increases Fatigue, Reduces Task Self-Efficacy, and Impairs Performance of Resistance Exercise. Sport Exerc. Perform. Psychol. 2017, 6, 70-88. [CrossRef]

39. Xu, A.J.; Loi, R.; Lam, L.W. The bad boss takes it all: How abusive supervision and leader-member exchange interact to influence employee silence. Leadersh. Q. 2015, 26, 763-774. [CrossRef] 
40. Huang, L.C.; Su, C.H.; Lin, C.C. The influence of abusive supervision on employees' motivation and extra-role behaviors: The daily-basis investigation. Chin. Manag. Stud. 2019, 13, 514-530. [CrossRef]

41. Jung, H.S.; Yoon, H.H. What does work meaning to hospitality employees? The effects of meaningful work on employees' organizational commitment: The mediating role of job engagement. Int. J. Hosp. Manag. 2016, 53, 59-68. [CrossRef]

42. Musavimoghadam, S.R.; Naranji, F.; Mohazab, L. The relationship between tendency to prayer, meaning of life and social competence among employees of ilam gas company. Res. J. Pharmacol. 2016, 10, 13-16. [CrossRef]

43. Albright, J.J.; Park, H.M. Confirmatory Factor Analysis Using Amos, Lisrel, Mplus, SAS/STAT CALIS; Indian University Information Technology Service Publishing: Kokomo, IN, USA, 2009; Available online: https://hdl.handle.net/2022/19736 (accessed on 10 September 2021).

44. Tabachnick, B.G.; Fidell, L.S. Using Multivariate Statistics, 5th ed.; Pearson Education: Boston, MA, USA, 2007.

45. Goudarzi, E.; Ghonsooly, B.; Pishghadam, R. An exploration of the interrelationships among EFL learners' English self-efficacy, metacognitive awareness, and their test performance. Pragmat. Cogn. 2014, 22, 325-339. [CrossRef]

46. Özdamar, K. Paket Programlar ile İstatistik Veri Analizi, 4th ed.; Kaan Kitabevi: Eskisehir, Turkey, 2002.

47. Karagöz, Y.; Kösterelioğlu, İ. İletişim Becerileri Değerlendirme Ölçeğinin Faktör Analizi Metodu ile Geliştirilmesi. Dumlupınar Üniversitesi Sosyal Bilimler Enstitüsü Dergisi (Development of Communication Skills Assessment Scale by Factor Analysis). Method J. Dumlupinar Univ. Inst. Soc. Sci. 2008, 21, 81-98.

48. Sipahi, E.; Artantaş, E. Artificial intelligence in HRM. In Handbook of Research on Innovative Management Using AI in Industry 5.0; Garg, V., Goel, R., Eds.; IGI Global: Hershey, PA, USA, 2022; pp. 1-18. [CrossRef]

49. Santiago, G.M. An extended model of the interaction between work-related attitudes and job performance. Int. J. Product. Perform. Manag. 2016, 65, 42-57. [CrossRef]

50. Rad, F.G.; Heidari, A. Relationship between cooperative learning and test anxiety with self-efficacy and academic performance in student. Indian J. Public Health Res. Dev. 2017, 8, 298. [CrossRef]

51. Makarov, D.; Miller, S.; Vahdatikhaki, F.; Dorée, A. Comprehensive real-time pavement operation support system using machineto-machine communication. Int. J. Pavement Res. Technol. 2020, 13, 93-107. [CrossRef]

52. Trujillo, B.A.E.; Colorado, D.; Rivera, W. Neural network and polynomial model to improve the coefficient of performance prediction for solar intermittent refrigeration system. Sol. Energy 2016, 129, 28-37. [CrossRef]

53. Kisi, O. Pan evaporation modeling using least square support vector machine, multivariate adaptive regression splines and M5 model tree. J. Hydrol. 2015, 528, 312-320. [CrossRef]

54. Neal, A.; Griffifin, M.A. A study of the lagged relationships among safety climate, safety motivation, safety behavior, and accidents at the individual and group levels. J. Appl. Psychol. 2006, 91, 946-953. [CrossRef] [PubMed]

55. Zhang, X.; Sun, Z.; Niu, Z.; Sun, Y.; Wang, D. The Effect of Abusive Supervision on Safety Behaviour: A Moderated Mediation Model. Int. J. Environ. Res. Public Health 2021, 18, 12124. [CrossRef]

56. Kelly, K. Better Than Human: Why Robots Will-And Must-Take Our Jobs. Wired, 24 December 2012. Available online: https: / www.wired.com/2012/12/ff-robots-will-take-our-jobs / (accessed on 3 September 2021). 